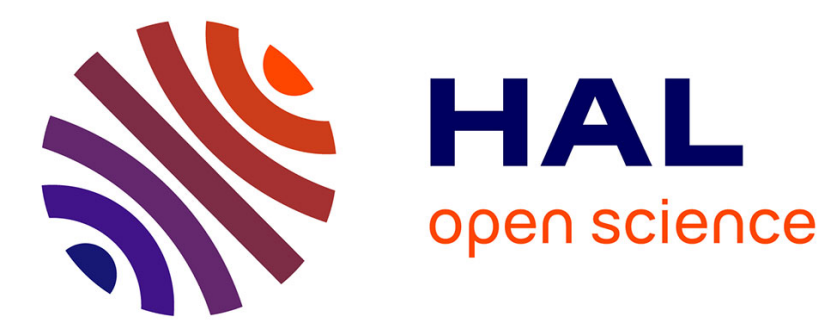

\title{
Remarkable Breakdown Voltage on AlN/AlGaN/AlN double heterostructure
}

Idriss Abid, Riad Kabouche, F Medjdoub, Sven Besendörfer, Elke Meissner, Joff Derluyn, Stefan Degroote, Marianne Germain, Hideto Miyake

\section{- To cite this version:}

Idriss Abid, Riad Kabouche, F Medjdoub, Sven Besendörfer, Elke Meissner, et al.. Remarkable Breakdown Voltage on AlN/AlGaN/AlN double heterostructure. 32nd International Symposium on Power Semiconductor Devices and ICs (ISPSD 2020), Sep 2020, Vienne, Austria. pp.310-312, 10.1109/ISPSD46842.2020.9170170 . hal-03044195

\section{HAL Id: hal-03044195 \\ https://hal.science/hal-03044195}

Submitted on 7 Dec 2020

HAL is a multi-disciplinary open access archive for the deposit and dissemination of scientific research documents, whether they are published or not. The documents may come from teaching and research institutions in France or abroad, or from public or private research centers.
L'archive ouverte pluridisciplinaire HAL, est destinée au dépôt et à la diffusion de documents scientifiques de niveau recherche, publiés ou non, émanant des établissements d'enseignement et de recherche français ou étrangers, des laboratoires publics ou privés. 


\section{Remarkable Breakdown Voltage on AlN/AlGaN/AlN double heterostructure}

\author{
I. Abid*, R. Kabouche and F. Medjdoub* \\ Institute of Electronics, Microelectronics and \\ Nanotechnology (IEMN), CNRS, \\ Lille, France \\ idriss.abid.etu@univ-lille.fr; farid.medjdoub@iemn.fr
}

\author{
J. Derluyn, S. Degroote, M. Germain \\ EpiGaN, Kempische Steenweg 293, 3500 \\ Hasselt, Belgium
}

\begin{abstract}
Ultra wide band gap (UWBG) materials such as AIN are part of a class of materials that have a larger band gap than conventional wide band gap (WBG) materials such as GaN, allowing higher operating voltages. In this work we present the fabrication and DC / high voltage characterizations of AIN/AIGaN/AIN double heterostructure that are regrown by metalorganic chemical vapor deposition on AIN/sapphire. A buffer breakdown about $1100 \mathrm{~V}$ with low leakage current for a spacing below $2 \mu \mathrm{m}$ is reported, which corresponds to a breakdown field about $6 \mathrm{MV} / \mathrm{cm}$. Furthermore, transistors have been successfully fabricated on this heterostructure with low leakage current and low on-resistance. A breakdown voltage of $4.5 \mathrm{kV}$ with an off-state leakage current below $0.1 \mu \mathrm{A} / \mathrm{mm}$ have been indeed achieved. These results that AIGaN-channel HEMTs are promising for high power, high temperature future applications.
\end{abstract}

Keywords- AlGaN channel; High-Electron-Mobility Transistor (HEMT); Ultra-Wide Band Gap, AIN

\section{INTRODUCTION}

GaN-based HEMTs and SiC power semiconductors are the material of choice for high power applications owing to their superior breakdown voltage (about 10 times) over their $\mathrm{Si}$ competitors. Today, the WBG-based electronics are maturing rapidly and have found large-scale market adoption in electric vehicles, power supplies, and photovoltaic (PV) inverters. However, ultra-wide band gap materials such as AlN $(6.2 \mathrm{eV})$ and related Al-rich AlGaN channel could allow for further improvement, especially in terms of voltage and temperature operations [1-7]. In addition, the use of an AlN back barrier [810] would enable to both increase the electron confinement in the transistor channel and enhance the thermal dissipation. It has already been demonstrated that for extremely high temperature electronics, the properties of Al-rich transistors are already showing favorable comparisons to conventional WBG materials [11]. Nevertheless, very high voltage operation is still plagued by the material quality and the ability to implement high $\mathrm{Al}$ content above $50 \%$ into the channel. The premise of voltage enhancement with $\mathrm{AlGaN}$ channels needs validation.

\author{
S. Besendörfer, E. Meissner \\ Fraunhofer Institute for Integrated Systems and Device \\ Technology IISB \\ Erlangen, Germany

\section{H. Miyake} \\ Department of Electrical and Electronics Engineering \\ Mie University, \\ Mie 514-8507, Japan
}

In this work, we demonstrate, state-of-the-art 3-terminal breakdown voltage (BV) for AlGaN channel HEMTs with multiple kilovolts.

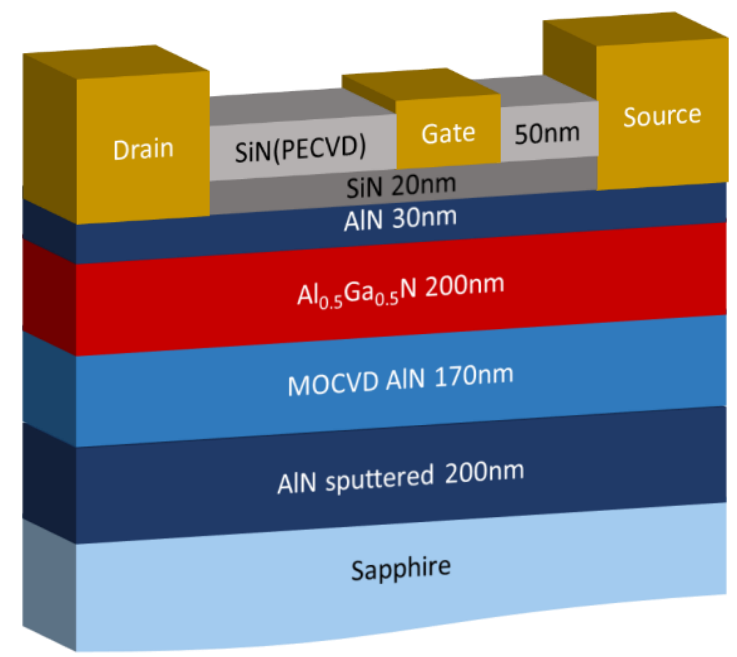

Fig. 1 : Schematic cross section of the AlN/AlGaN/AIN HEMTs

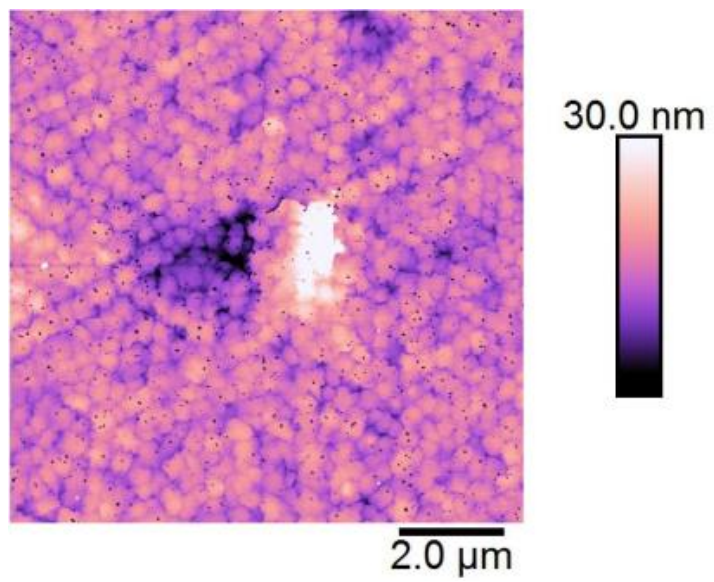

Fig. 2 : Schematic cross section of the AlN/AlGaN/AlN HEMTs 


\section{MATERIAL DESCRIPTION AND DEVICE FABRICATION}

Fig. 1 shows a cross-sectional drawing of the fabricated AlGaN channel HEMT. An AlN film with $200 \mathrm{~nm}$ thickness was grown on c-plane sapphire substrates by sputtering followed by annealing at $1700^{\circ} \mathrm{C}$ for $3 \mathrm{~h}$. Epitaxial layers, consisting of a 170-nm-thick AlN buffer, a 200-nm-thick $\mathrm{Al}_{0.5} \mathrm{Ga}_{0.5} \mathrm{~N}$ channel, and a 30 -nm-thick $\mathrm{AlN}$ barrier capped with a 20 -nm thick SiN layer, were grown by metal-organic vapour phase epitaxy. All the layers were unintentionally doped. Fig. 2 shows an AFM image of the as grown structure, where the surface mirrors dislocation mediated island growth induced by screw type threading dislocations. This reflects the large room for improvement in terms of material quality. Source/drain ohmic contacts were obtained by etching the SiN cap as well as part of the AlN barrier with a deposition of a $\mathrm{Ti} / \mathrm{Al} / \mathrm{Ni} / \mathrm{Au}$ metal stack annealed at $875^{\circ} \mathrm{C}$.

As expected from previous work on AlGaN channel, high contact resistances are observed. Si implantation or highly doped regrowth layer would be needed to achieve low contact resistances. Device isolation has been performed by mesa etching. A 2DEG charge density of $1.9 \times 10^{13} \mathrm{~cm}^{-2}$ with an electron mobility of $145 \mathrm{~cm}^{2} / \mathrm{V}$.s has been measured on Van der Pauw patterns. Ni/Au MIS gates were deposited on top of the $\mathrm{SiN}$ cap layer.
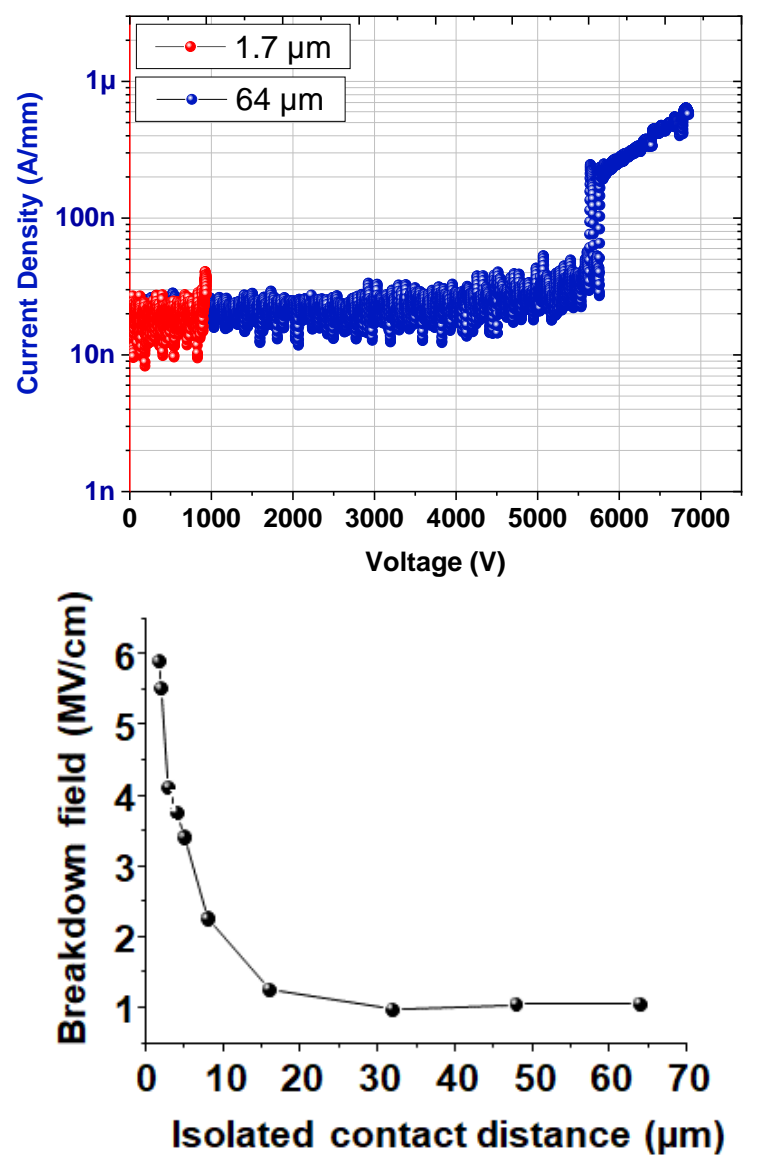

Fig. 3 : Buffer BV and breakdown field for various contact distances of AlN/AlGaN/AlN HEMTs

\section{RESULTS AND DISCUSSION}

Buffer BV on isolated contacts for various distances appears in Fig. 3. It can be noticed that the buffer breakdown reaches about $1000 \mathrm{~V}$ with low leakage current for a spacing as low as $1.7 \mu \mathrm{m}$, which corresponds to a remarkable breakdown field close to $6 \mathrm{MV} / \mathrm{cm}$. For larger spacing, significant lateral buffer BV up to $7 \mathrm{kV}$ has been measured, using a Keysight B1505A with N1268A Ultra High Voltage Expander. It can be pointed out that the BV drop for larger contact distances is mainly limited by the sapphire substrate, which has about 0.5 $\mathrm{MV} / \mathrm{cm}$ breakdown strength.
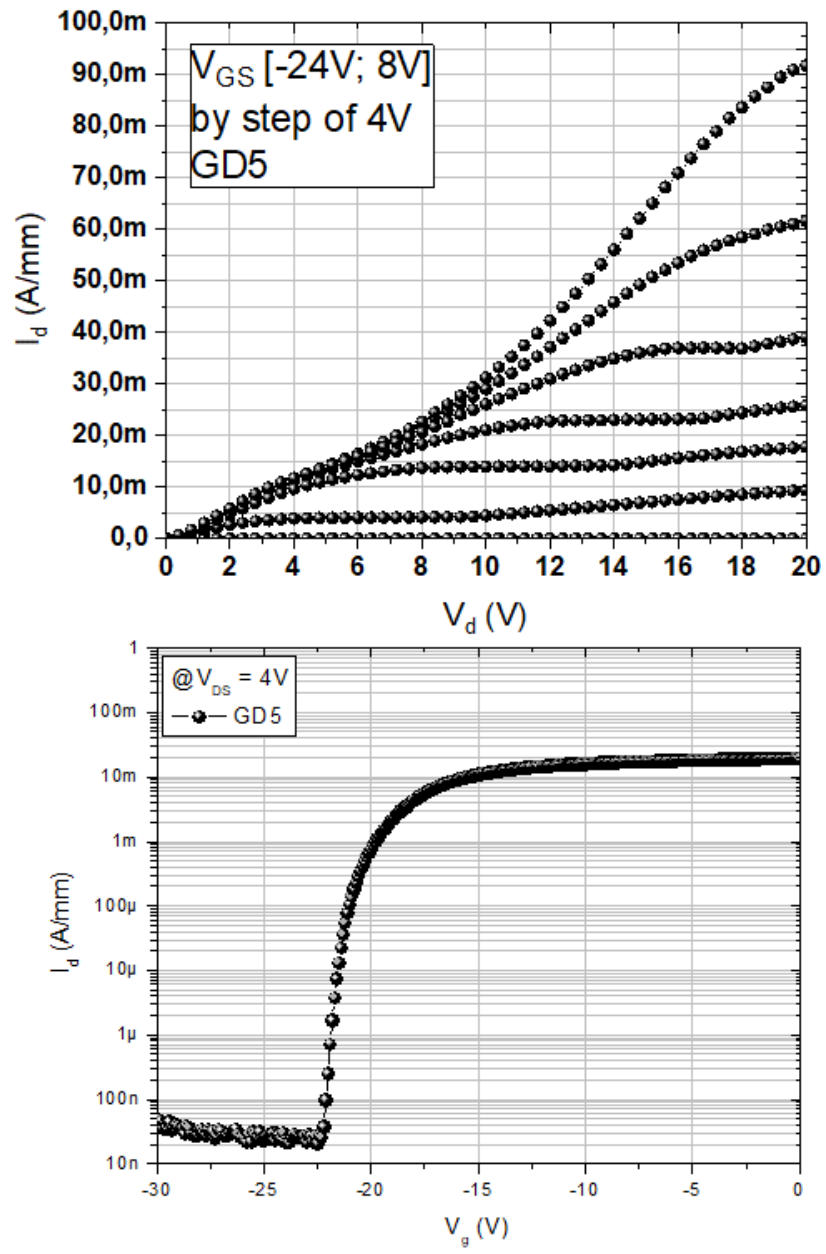

Fig. 4 : Output characteristics and transfer characteristics for a gate-drain distance of $5 \mu \mathrm{m}$ of AlN/AlGaN/AIN HEMTs

DC characteristics show fully functional devices (Fig 4). Although the ohmic contacts are quite poor, a maximum current density above $90 \mathrm{~mA} / \mathrm{mm}$ with an off-state leakage current around $20 \mathrm{nA} / \mathrm{mm}$ has been obtained on devices with gate width/length $=50 \mu \mathrm{m} / 1.5 \mu \mathrm{m}$ and gate-to-drain spacing $\left(\mathrm{L}_{\mathrm{GD}}\right.$ ) of $5 \mu \mathrm{m}$ (yielding an $\mathrm{I}_{\mathrm{ON}} / \mathrm{I}_{\mathrm{OFF}}$ ratio close to $10^{6}$ ). Strong pinch-off and no punch-through effects are observed owing to the efficient AlN back barrier. Low leakage current is obtained without the use of field plates confirming that tunneling mechanisms are not present in Al-rich transistors. In general, Al-rich transistors are less prone to gate leakage than 
AlGaN/GaN HEMTs. The corresponding specific on-resistance $\mathrm{R}_{\mathrm{ON}}$ ranges from 5.5 to $9.5 \mathrm{~m} \Omega . \mathrm{cm}^{2}$ for the various transistor designs. Finally, Fig 5 show the 3-terminal BV as a function of the transistor gate-drain distance measured at $\mathrm{V}_{\mathrm{GS}}=-25 \mathrm{~V}$. Despite the rather high defect density, a record BV of $4500 \mathrm{~V}$ with an off-state leakage current below $0.1 \mu \mathrm{A} / \mathrm{mm}$ is achieved for AlGaN-based channel HEMTs. It can be noticed that low gate-drain of $5 \mu \mathrm{m}$ yields a breakdown field of $3.5 \mathrm{MV} / \mathrm{cm}$, which is well-beyond that of $\mathrm{SiC}$ and $\mathrm{GaN}$ devices.
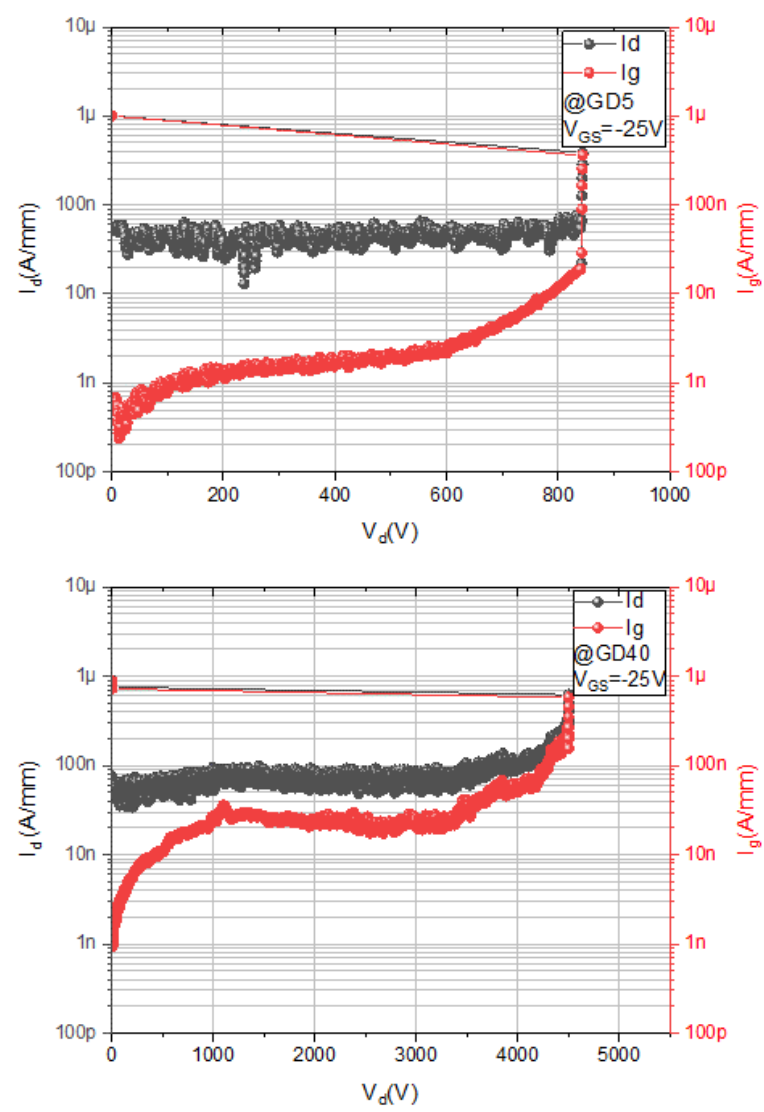

Fig. 5: 3-terminal off-state $B V$ for various $G D$ distances of AlN/AlGaN/AlN HEMTs

\section{CONCLUSIONS}

In summary, Al-rich AlGaN channel combined with AlN material offers great potential as the material of choice for the next generation of transistors for power switching applications. We have shown the possibility to operate at high voltage using an AlN/AlGaN/AlN heterostructure with $50 \%$ $\mathrm{Al}$ content into the channel. This resulted in an increase in the critical electric field as compared to more standard GAN HEMTs. Further study of the breakdown mechanisms may offer insight toward increasing breakdown fields in Al-rich transistors.

Although epitaxial growth efforts have mainly been conducted on sapphire substrates, AlN may be the long-term best substrate for Al-rich transistors, in spite of its immaturity. Its advantages include a better thermal conductivity and a better crystalline quality due to near lattice-matched growth conditions for $\mathrm{Al}_{\mathrm{x}} \mathrm{Ga}_{1-\mathrm{x}} \mathrm{N}$ with large $\mathrm{x}$.

\section{ACKNOWLEDGMENT}

This work is supported by the French RENATECH network and the French National grant ANR-17-CE05-00131 within the project called BREAKUP and the project InRelNPower, which has received funding from the European Union's Horizon 2020 research and innovation programme under grant agreement No. 720527.

\section{REFERENCES}

[1] S. Bajaj, T.-H. Hung, F. Akyol, S. Krishnamoorthy, S. Khandaker, A. Armstrong, A. Allerman and S. Rajan, "Power switching transistors based on GaN and AlGaN channels", 2015 IEEE 3rd Workshop on Wide Bandgap Power Devices and Applications (WiPDA), 2015.

[2] T. Razzak, S. Rajan and A. Armstrong, "Ultra-wide bandgap AlxGa1xN channel transistors", International Journal of High Speed Electronics and Systems, Vol. 28, No 1\&2, 1940009 (2019).

[3] E. A. Douglas, B. Klein, A. Allerman, A. G. Baca, T. Fortune, and A. M. Armstrong, "Enhancement-mode Al0.45Ga0.55N/A10.3Ga0.7N high electron mobility transistor with p-A10.3Ga0.7N gate", Journal of Vacuum Science \& Technolog, 021208 (2019).

[4] T. Nanjo, M. Takeuchi, M. Suita, Y. Abe, T. Oishi, Y. Tokuda and Y. Aoyagi, "First operation of $\mathrm{AlGaN}$ channel high electron mobility transistors with sufficiently low resistive source/drain contact formed by Si ion implantation", 2007 International Conference on Solid State Devices and Materials, Tsukuba, 2007, pp. 164-165.

[5] Y. Wu, J. Zhang, S. Zhao, W. Zhang, Y. Zhang, X. Duan, J. Chen and Y. Hao, "More than $3000 \mathrm{~V}$ reverse blocking schottky-drain AlGaN channel HEMTs with > $230 \mathrm{M}$ W/cm 2 power figure-of -merit", IEEE Electron Device Letters, Vol 40, Issue: 11, 2019, pp. 1724 - 1727.

[6] A. G. Baca, B. A. Klein, A. A. Allerman, A. M. Armstrong, E. A. Douglas, C. A. Stephenson, T. R. Fortune, and R. J. Kaplar, "Al0.85Ga0.15N/A10.70Ga0.30N high electron mobility transistors with schottky gates and large On/Off current ratio over temperature", ECS Journal of Solid State Science and Technology, Vol 6 (12), 2017, Q161Q165.

[7] P. H. Carey, F. Ren, A. G. Baca, B. A. Klein, A. A. Allerman, A. M. Armstrong, E. A. Douglas, R. J. Kaplar, P. G. Kotula and S. J. Pearton, "Operation up to $500{ }^{\circ} \mathrm{C}$ of $\mathrm{Al} 0.85 \mathrm{Ga} 0.15 \mathrm{~N} / \mathrm{Al} 0.7 \mathrm{Ga} 0.3 \mathrm{~N}$ high electron mobility transistors", IEEE Journal of the Electron Devices Society, 2019, pp 99.

[8] S. Arulkumaran, T. Egawa and H. Ishikawa, "Enhancement of breakdown voltage in AlGaN/GaN HEMTs using AlN buffer layer thickness on 4-inch Silicon", 2004 International Conference on Solid State Devices and Materials, 2004, pp. 666-667.

[9] I. Abid, R. Kabouche, C. Bougerol, J. Pernot, C. Masante, R. Comyn, Y. Cordier, and F. Medjdoub, "High lateral breakdown voltage in thin channel AlGaN/GaN high electron mobility transistors on AlN/Sapphire templates", Micromachines, Vol 10, 2019.

[10] N. Yafune, S. Hashimoto, K. Akita, Y. Yamamoto, H. Tokuda and M. Kuzuhara, "AlN/AlGaN HEMTs on AlN substrate for stable hightemperature operation”, Electronics Letters, Vol 50, Issue: 3, 2014, pp 211-212.

[11] P. H. Carey IV, F. Ren, A. G. Baca, B. A. Klein, A. A. Allerman, A. M. Armstrong, E. A. Douglas, R. J. Kaplar, and S. J. Pearton, "Extreme Temperature Operation of Ultra-Wide Bandgap AlGaN High Electron Mobility Transistors”, IEEE Trans. Semicond. Manuf. 32, 473 (2019). 